\title{
Initial psychometric properties of the Inventory of Anticipatory Coping Skills for Abstinence from Alcohol and Other Drugs
}

\author{
Lucas Guimarães Cardoso de Sá ${ }^{1}$ \\ Universidade Federal do Maranhão, São Luís-MA, Brazil \\ Fabián Orlando Olaz \\ Universidad Nacional de Córdoba, Córdoba, Argentina \\ Zilda Aparecida Pereira Del Prette \\ Universidade Federal de São Carlos e Instituto Nacional de Ciência e \\ Tecnologia sobre Comportamento, Cognição e Ensino, São Carlos-SP, Brazil
}

\section{ABSTRACT}

The objective of this study was to investigate the initial psychometric properties of the Inventory of Anticipatory Coping Skills for Abstinence from Alcohol and Other Drugs (Inventário de Habilidades de Enfrentamento Antecipatório para a Abstinência de Álcool e Outras Drogas - IDHEA-AD). The total sample included 457 individuals in treatment for problems related to alcohol or crack use. An Exploratory Factor Analysis, Maximum Likelihood Extraction and Promax rotation were used, which produced a structure of 30 items distributed across three factors: "assertiveness and planning for high-risk substance use situations", "expression of positive feelings towards abstinence" and "emotional self-control in adverse situations". After analyzing validity evidence based on the internal structure and reliability based on internal consistency, it was possible to conclude that this structure included important behaviors for the relapse prevention.

Keywords: adaptation psychological; social skills; crack cocaine; alcoholism; substance-related disorders.

RESUMO - Propriedades Psicométricas iniciais do Inventário de Habilidades de Enfrentamento Antecipatório para a Abstinência de Álcool e Outras Drogas

O objetivo deste estudo foi investigar as propriedades psicométricas iniciais do Inventário de Habilidades de Enfrentamento Antecipatório para a Abstinência de Álcool e Outras Drogas (IDHEA-AD). A amostra foi de 457 pessoas em tratamento por problemas relacionados ao uso de álcool ou crack. Foi realizada uma Análise Fatorial Exploratória, método de extração Máxima Verossimilhança e rotação Promax, que produziu uma estrutura de 30 itens, distribuídos em três fatores, nomeados como "assertividade e planejamento para situações de alto risco de consumo de substâncias", "expressão de sentimentos positivos para a abstinência" e "autocontrole emocional em situações adversas". Analisadas evidências de validade de estrutura interna e fidedignidade por consistência interna, concluiu-se que a estrutura é adequada para a avaliação de comportamentos direcionados à prevenção de recaídas.

Palavras-chave: adaptação psicológica; habilidades sociais; cocaína crack; alcoolismo; transtornos relacionados ao uso de substâncias.

RESUMEN - Propiedades psicométricas iniciales del Inventario de Habilidades de Afrontamiento Anticipatorio para la Abstinencia de Alcohol y otras Drogas

El objetivo de este estudio fue investigar las propiedades psicométricas iniciales del Inventario de Habilidades de Afrontamiento Anticipatorio para la Abstinencia de Alcohol y otras Drogas (IDHEA-AD). La muestra fue de 457 personas en tratamiento por problemas relacionados al uso de alcohol o crack. Se realizó un Análisis Factorial Exploratorio, con método de extracción de Máxima Verosimilitud y rotación Promax, que dio como resultado una estructura de 30 ítems, distribuidos en tres factores, nombrados como "asertividad e planeamiento para situaciones de alto riesgo de consumo de sustancias", "expresión de sentimientos positivos para la abstinencia" y "autocontrol emocional en situaciones adversas". Se concluye que el IDHEA-AD es un instrumento considerable para la prevención de recaídas, en base a la evidencia de validez de estructura interna obtenida y a estudios de confiabilidad por consistencia interna realizados.

Palabras clave: adaptación psicológica; habilidades sociales; cocaína crack; alcoholismo; transtornos relacionados con sustancias. 
Relapse prevention, based on a cognitive-behavioral model, focuses on the development of intra- and interpersonal coping skills, which contribute decisively to prevent an individual from returning to the consumption of a substance after a period of abstinence (Marlatt $\&$ Witkiewitz, 2009). Although the importance of coping skills in maintaining abstinence has been reported since the 1970s (Van Hasselt, Hersen, \& Milliones, 1978), little attention has been paid to psychometric studies that aim to develop or improve instruments to evaluate this specific construct.

Relapse prevention and abstinence from substances require inter- and intrapersonal anticipatory behaviors (Donovan, 2009) and those that are adaptive to consumption risk situations. These anticipatory behaviors include thoughts and actions targeted at building an environment that is less susceptible to stressful situations, or aim for a fast and effective resolution before they can cause craving, which consequently decreases the likelihood of a lapse or relapse.

Intrapersonal skills include strategies the individual uses in order to face a problematic situation. Although other individuals may be a component of the context, they are not directly involved in performing this skill. Examples of these skills include the following: identification, escape from risk situations and avoidance of them, problem solving, decision making and cognitive restructuring to establish a favorable environment for abstinence (Monti, Kadden, Rohsenow, Cooney, \& Abrams, 2005; Rangé \& Marlatt, 2008).

Interpersonal coping skills can be characterized as classes of social skills, in which the behavior of the individual directly depends on the interaction with the interlocutor, such as assertiveness and the expression of positive and negative feelings (Del Prette \& Del Prette, 2012; Rangé \& Marlatt, 2008; Sakiyama, Ribeiro, \& Padin, 2012; Schneider, Limberger, \& Andretta, 2016).

The literature has historically shown that social skills deficits are a risk factor for many problems and psychological disorders, whereas an elaborate repertoire of these skills is considered a protective factor (Caballo, 2003; Del Prette \& Del Prette, 2002; Trower, 1995). In recent years, researchers have found evidence that

- coping skills deficits may be associated with excessive use of alcohol (Felicissimo, Casela, \& Ronzani, 2013), marijuana (Wagner, Silva, Zanattelo, \& Oliveira, 2010) and crack (Horta et al., 2016);

- a wide repertoire of coping skills may reduce the risks of substance use disorders (Van Gundy, Howerton-Orcutt, \& Mills, 2015);

- coping skills deficit predicts substance use (Fathiandastgerdi, Eslami, Ghofranipour, Mostafavi, \& Ebrahimi, 2016);

- dysfunctional coping styles are directly connected to problems of alcohol use and indirectly connected to the regularity this substance is used (Blevins, Abrantes, \& Stephens, 2016).

Other results indicate specific assertiveness in refusing a drink or other drug offer as being connected to aspects of alcohol and other drug consumption. Some studies with non-addicted adolescents have shown this relationship. Scheier, Botvin, Diaz, and Griffin (1999) argue that a small repertoire of refusal skills is associated with alcohol involvement. Duncan, Duncan, Beauchamp, Wells, and Ary (2000) reported greater efficacy in refusing marijuana among young individuals who had participated in a multimedia program that taught them how to refuse this drug. Epstein, Zhou, Bang, and Botvin (2007) report that using refusal skills is linked to a lower likelihood of drinking.

For addicted individuals, the adequate execution of these skills would decrease the likelihood of cravings emerging, which could be generated by adopting passive or aggressive behavior in response to the insistence of others to consume a substance. Freedberg and Johnston (1978, cited by Monti et al., 2005) demonstrated that alcoholics who had experienced assertiveness training fared better on drinking behavior than a group that did not experience this intervention. In a two-year follow-up study, Ferrell and Galassi (1981) reported that patients who received assertiveness skills training maintained abstinence for a significantly longer period than those who received another type of treatment. Zywiak et al. (2006) suggest that substance refusal training is an active ingredient of therapy in the treatment of alcoholism.

Monti et al. (2005, p. 74) argue that "being offered a drink or being pressured by others to drink is a common high risk situation for alcoholics who have decided to stop drinking". For these authors, the social use of alcohol is widely accepted in Western culture and indicates that more than a sincere decision not to drink is required. Specific assertiveness skills must be developed for such a decision to be enforced, thus preventing harassment, whether casual or repeated, from leading to the appearance of cravings. Carroll (1998) follows the identical rationale and states that assertiveness in the form of refusal skills is fundamental for cocaine addicts who wish to maintain sobriety. According to Mares, and Torres (2010), if a firm refusal is provided, there is less likelihood of insistence on offering. Thus, an assertive refusal allows the individual to have control of the environment and reaffirms their conviction in not consuming the substance. The same authors presented results in which alcohol and marijuana addicts that received refusal skills training continued total abstinence or had few and isolated episodes of consumption in subsequent months. A similar result in a study involving African American alcoholics was reported by Witkiewitz, Aracelliz, Hartzler, and Donovan (2011). Dolan, Rohsenow, Martin, and Monti (2013) presented 
results indicating that the ability to refuse an alcohol offer at the moment of craving was higher in abstinent individuals who had lapses after treatment.

Although studies on coping skills, associated with different ways of consumption and abstinence, have mushroomed in recent years, most attention has been given to investigations of assertiveness. Such lack of investigation compromises the studies of other processes of relapse prevention as important as assertiveness, mainly the ones related to intrapersonal skills, which have had little attention. Such a gap can be connected to the fact that intrapersonal coping skills seem to be more complex to be taught (Monti et al., 2005), or even investigated. Some studies involved decision making (Barkin, Smith, \& DuRant, 2002), aggressiveness self-regulation (Felicissimo, Santos, Fontoura, \& Ronzani, 2016; Wagner \& Oliveira, 2009; Wagner et al., 2010) and the ability to deal with negative emotion such as anger or sadness (Rahman, Rahaman, Hamadani, Mustafa, \& Islam, 2016; Ritchie, Weldon, Freeman, MacPherson, \& Davies, 2011; Zywiak et al., 2006).

Another gap, as mentioned by Sá and Del Prette (2014), is the low number of psychometric studies showing the construction, development, and the reliability and validity of the instruments used to evaluate the coping skills repertoire of addicts. This gap may be specially a problem because of the situational cultural character of coping skills (Del Prette \& Del Prette, 2009), which suggests the need to identify, evaluate and promote those skills which are critical to the demands, contexts and social contacts associated with substance use or abuse behavior, accounting for the culture or subculture of the individual. Therefore, the evaluation and promotion of coping with the inherent intra- and interpersonal demands of abstinence, in the case of Substance Use Disorder, has some particularities that cannot be reliably captured by global coping skills measures, even when focusing on assertiveness. A more detailed analysis of situations, demands and specific behaviors associated with this context is therefore necessary (Litt, Kadden, \& Tennen, 2012). Only recently there has been concern with the development of valid and reliable instruments to evaluate coping skills specific to Substance Use Disorder (Humke \& Radnitz, 2005; Litt et al., 2012; Rohsenow, Martin, \& Monti, 2005). However, until recently, no research in this area has been reported in Brazil.

Because the adaptation of foreign instruments may not adequately consider the characteristics of the Brazilian population and no instruments have exclusively evaluated anticipatory coping, considering components other than assertiveness, Sá and Del Prette (2016) developed the Inventory of Anticipatory Coping Skills for Abstinence from Alcohol and Other Drugs (Inventário de Habilidades de Enfrentamento Antecipatório para a Abstinência de Álcool e Outras Drogas - IDHEA-AD). In Brazil, the current guidelines regarding the use of psychological evaluation instruments (CFP, 2010), which are based on international recommendations, such as those presented in the Standards for Educational and Psychological Testing (AERA, APA, \& NCME, 1999), provide that an instrument must demonstrate validity and reliability evidences that attest to its quality before being used in professional practice. Thus, based on this requirement, the objective of this study was to investigate the initial psychometric properties of the IDHEA-AD, analyzing validity evidence based on the internal structure, and reliability based on internal consistency.

\section{Method}

\section{Participants}

The study included 457 individuals who sought voluntary treatment in public services or substance addiction charities because of problems related to alcohol or crack use. After an analysis of the missing data and atypical observations, 422 participants comprised the final sample used in the analysis. Of these participants, $58 \%$ reported being in treatment for problems related to the consumption of crack, although they also used alcohol. The remaining participants stated that they were in treatment for problems related to alcohol use without reporting the use of illegal substances.

The majority of the sample consisted of males (85.5\%). The mean age of participants was 36.66 years old $(S D=12.25)$ with a significant statistical difference between those in treatment for alcohol use $(M=45.06 ; S D=10.04)$ and crack $(M=30.48 ; S D=9.83 ; t=14.75, \quad p<0.001$, $d=1.47$ ). Also, the sample had mostly a low educational level: $55.6 \%$ had only completed primary education, $36.3 \%$ secondary education and $8.1 \%$ higher education.

Regarding the treatment mode, $78 \%$ were outpatients in semi-intensive care units, which corresponded to treatment of up to eight daily hours for a maximum of five days per week. The other $22 \%$ were inpatients with an intensive regimen, namely, 24 hours of treatment, seven days a week. The abstinence period of participants was an average of 3.57 months $(S D=10.01)$. A significant statistical difference, but with a small effect size, was observed between the means of crack $(M=2.57$; $S D=4.62)$ and alcohol users $(M=4.97 ; S D=14.95$; $t=2.41, p<0.05 ; d=0.23)$.

\section{Instrument}

The instrument was the initial version of the IDHEA-AD, developed by Sá and Del Prette (2016). The instrument had 67 initial items; each item evaluated the frequency of a coping behavior in a particular situation, as reported by the respondent on a scale with four response points. For example, on the item "If someone I know insists on offering me a drink, I ask them to stop", the respondent would have to choose one of the following response options: never, rarely, often or always. 


\section{Procedures}

After approval by the Research Ethics Committee (Protocol 0055.0.135.000-10), the data collection was performed at the treatment sites where participants sought care, including only public health care centers or addiction recovery charities. Following ethical procedures, the researcher or one assistant were always present during the data collection, in order to give participants instructions, supervise all steps of the process, answer possible questions and check if all the questions had been answered.

The instrument was applied in two different ways. For illiterate participants or individuals with trouble reading, the questions were read out loud by the researcher or the researcher-assistant. The answers were then written down on the proper form. For participants with greater reading skills, the form was delivered, so they could independently read the questions and checked the answers.

Exclusion criteria included underage people, being under the apparent influence of alcohol or other drugs at the time of collection or presenting with a comorbidity that would hinder an understanding of the questions. Even though the participant could not have interrupted the use of alcohol or other drugs completely, one should necessarily be under volunteer treatment to start or keep the abstinence of the substance.

The responses were entered into a spreadsheet (PASW Statistics v. 18), a series of preliminary steps were performed, and prerequisites were checked to prepare and adjust the sample for the Exploratory Factor Analysis (EFA). These steps are briefly described next.

1. The analysis of missing data and possible outliers. A total of 18 participants were excluded because they failed to answer to more than $10 \%$ of the questions, which was the maximum value tolerated for missing values per case (Hair, Black, Babin, Anderson, \& Tatham, 2009). For the 439 remaining participants, only $0.4 \%$ of the total data had not been completed, and this small percentage was distributed over 54 of 67 variables. The highest percentage of missing data for a single variable was $1.1 \%$, which was below the $5 \%$ tolerated (Tabachnik \& Fidell, 2007). These results indicated the randomness of the missing data with the absence of a pattern that would suggest problems with the instrument items. Therefore, any method of completing such data could be used without much risk of biasing the subsequent analyses. The Expectation Maximization (EM) method was selected because it is considered the most simple and rational one for data completion and is particularly suitable for techniques such as EFA, according to Tabachnik and Fidell (2007). To investigate the univariate outliers, the data were transformed into $Z$-scores, and no cases were observed with a value over 3.29. Leverage and Mahalanobis distance values were analyzed to assess multivariate outliers. In the first distance value, no value was greater than one, but in the second distance value, 17 cases were eliminated because $\chi^{2}$ values were greater than 108.53, calculated for 67 degrees of freedom and $p<0.001$.

2. Checking the assumptions for performing multivariate techniques. Normality was tested by visual inspection of the histogram, Q-Q charts and skewness and kurtosis values, which produced acceptable values according to the adequacy criterion proposed by Hair, Babin, Money, and Samouel (2005). The assumption of linearity was sustained using scatterplots between different pairs of variables. Homoscedasticity was inferred from the observation that the standard deviations of the variables were low and that the difference between their smallest and largest variance was small. Excess multicollinearity was discarded when the following scenarios were encountered: correlations below 0.90 , proportional variances below 0.50 , tolerance values above 0.10 (values encountered between 0.41 and 0.81 ), and a variance inflation factor (VIF) below 10 (values encountered between 1.23 and 2.44), critical values according to Hair et al. (2009).

3. The analysis of sampling adequacy indices for the EFA. Significant correlations were observed between the variables with approximately one-half exceeding 0.30 . The value of the correlation matrix determinant was different from zero. Bartlett's test was significant $\left(\chi^{2}=9300.44 ; d f=2211 ; p<0.001\right)$. The anti-image correlation matrix showed low partial correlations and measures of sampling adequacy (MSA) for variables ranging between 0.38 and 0.95 . Because values below 0.50 are unacceptable, the variable (item) called "refuse favor" was excluded $(\mathrm{MSA}=0.38)$. A new anti-image correlation matrix was generated without this variable, and no value was below 0.50 . However, the item "avoid thinking about problems" and "deal with teasing by avoiding contact with others" were excluded because they had MSA values of 0.60 and 0.64 , respectively, which were below the 0.70 minimum recommended as ideal. Sampling adequacy measures for the variables ranged between 0.72 and 0.95 . The overall adequacy index (Kaiser-Meyer-Olkin Index $=0.88$ ) was adequate, according to Hair et al. (2009).

The above-described procedures indicated adequacy of the data for performing EFA. New procedures were therefore adopted for the rest of the study. Initially, a Principal Component Analysis was performed without defining the number of factors and without the choice of rotation method or deletion of variables according to factor loading. Tabachnik and Fidell (2007) suggest that this 
method can be a prior step to EFA because of its usefulness in generating information regarding the factors to be extracted and their characteristics. The scree plot was verified, and a Horn's parallel analysis was performed to determine more precisely the maximum number of possible factors to be obtained. The EFA was then performed using the Maximum Likelihood method with Promax rotation, because there was an assumption of correlation between the factors, as observed in the factor matrix. The analysis was performed by requesting the maximum number of factors indicated by Horn's parallel analysis with the deletion of items with a factor loading lower than 0.40, as recommended by Field (2005), and considered rigorous by Hair et al. (2009) and Tabachnik and Fidell (2007).

\section{Results}

In the Principal Component Analysis, the communality values of the 64 instrument items varied between 0.38 and 0.74 . According to the Kaiser criterion, the variables comprised a maximum of 16 components with a total explained variance of $57.89 \%$. However, as Costello and Osborne (2005) indicated, the Kaiser criterion can often overestimate the number of possible dimensions to be extracted, which occurred in this case, once that an analysis of the scree plot (Figure 1) reveals a structure with up to five components. The result of Horn's parallel analysis (Figure 2) corroborated this result and suggested five factors as the maximum number for extraction, since the first five eigenvalues extracted from the actual data are larger than the corresponding $95^{\text {th }}$ percentile random eigenvalue data.

Based on these indications, the EFA was re-performed requesting the extraction of five factors. However, this analysis produced a factor with low reliability and another with only two items, which indicated that the structure was not adequate and required revision. A second analysis was performed requesting the extraction of four factors, though this analysis did not show satisfactory results, because of the low reliability of one of the factors, thus provoking a new revision of the model, this time requesting the extraction of three factors. This trifactorial structure was considered adequate

Scree Plot

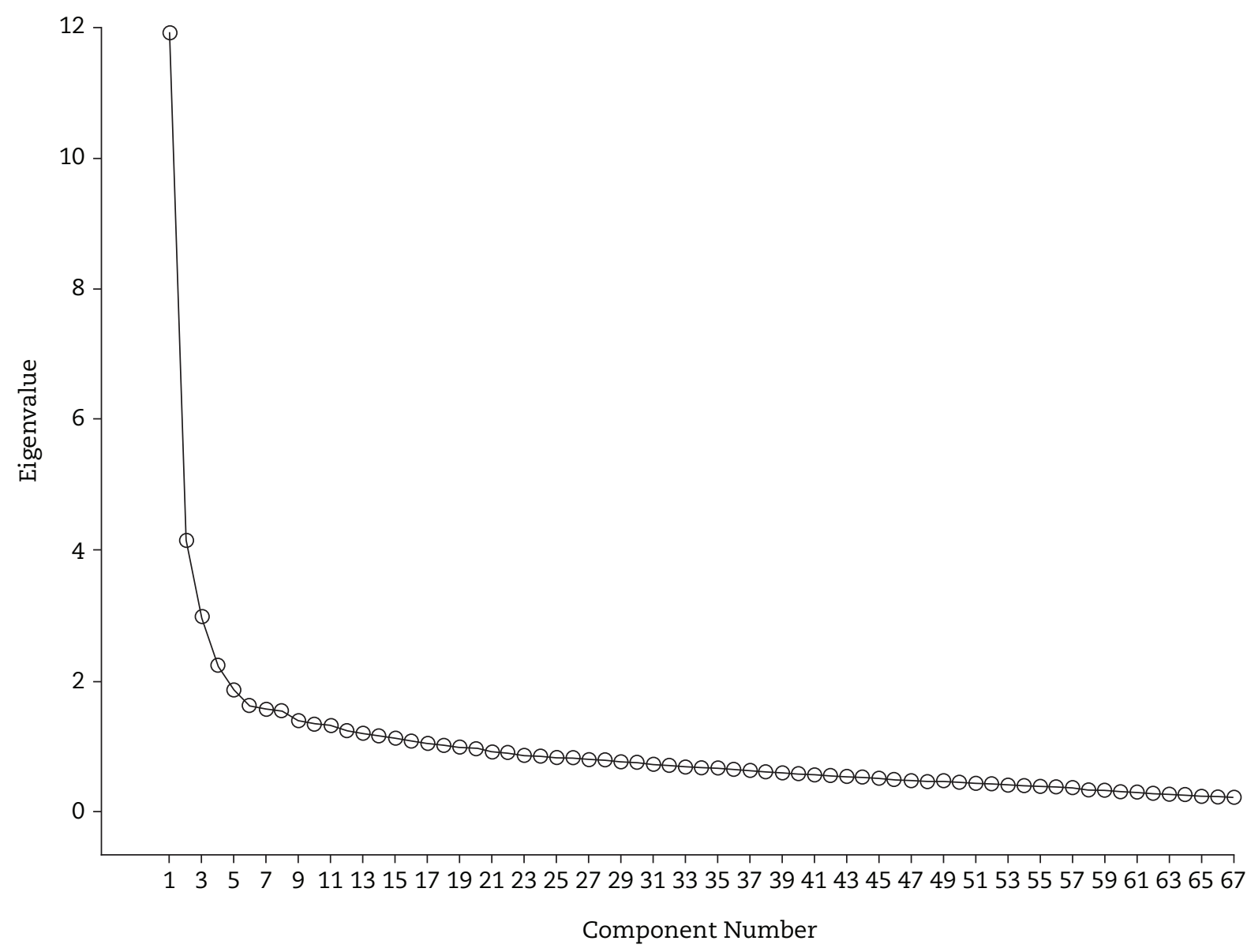

Figure 1. The scree plot generated by the software SPSS for Windows 18 that suggests an extraction of up to five factors 
because it was simple, theoretically obvious and reliable (Table 1). It retained 30 items with a total explained variance of $43.02 \%$, communalities between 0.21 and 0.57 and high overall precision $(\alpha=0.88)$.

The first factor (F1) was "assertiveness and planning for high-risk substance use situations" and mainly involved substance offer refusal skills (14 items, Cronbach's alpha $=0.89$ and scores between 0 and 42). The second factor (F2), "Emotional expression of positive feelings for the maintenance of abstinence", encompassed skills demonstrating feelings that contributed to establishing less stressful social situations (eight items, Cronbach's alpha $=0.83$ and scores between 0 and 24). The third factor (F3), "emotional self-control in adverse situations", mainly involved anger management (eight items, Cronbach's alpha $=0.77$ and scores between 0 and 24). There was a moderate Pearson's correlation between F1 and F3 (0.46) and weak correlations between F1 and F2 (0.17), and F2 and F3 (0.18).

\section{Discussion}

The structure of the IDHEA-AD remained stable in all extractions, regardless of the number of requested factors. The three dimensions that comprised the final version of the instrument were always present, thus conserving the identical order in terms of percentage of explained variance after each extraction. The greatest difficulty in the process was achieving a structure that was reliable when analyzed in both its entirety and in sections, which was accomplished with the three-factor structure. In this structure, the F1 is related to assertiveness, F2 to the expression of positive feelings and F3 to emotional self-control.

In the extractions prior to the final structure, two groups of items were identified. F1, which consisted of only two questions, was related to coping with the distrust of others, particularly family members, regarding possible "hidden" substance use. However, in addition to the low reliability, the small number of items precluded the interpretation of the factor. It was expected that, on subsequent extractions, these items could be relocated to other factors such as emotional expression of negative or positive feelings or even assertiveness. However, this scenario did not materialize, and one explanation may be that because this skill is possibly a multifactorial skill, it could not maintain reliability in any other factor. Another possibility is that this factor may form an independent factor, but its theoretical

PARALLEL ANALYSIS REPORT

By Ruben Ledesma \& Pedro Valero Mora

MODEL: Planilha Analise Paralela

VARIABLES: (Var1 Var2 Var3 Var4 Var5 Var6 Var7 Var8 Var9

Model: (Principal Component of correlation matrix)

Method: (Normal Data Simulation)

Number of simulated samples: 100

Eigenvalues at percentile: 95.0

\begin{tabular}{lccc}
\hline & Observed & Mean & Perc95.0 \\
\hline Eigenvalue 1 & 11.90321 & 1.86029 & 1.93092 \\
Eigenvalue 2 & 4.11039 & 1.78603 & 1.84510 \\
Eigenvalue 3 & 2.96034 & 1.72799 & 1.77572 \\
Eigenvalue 4 & 2.16375 & 1.68070 & 1.74170 \\
Eigenvalue 5 & 1.85985 & 1.63778 & 1.68714 \\
Eigenvalue 6 & 1.56428 & 1.59960 & 1.64605 \\
Eigenvalue 7 & 1.51711 & 1.56320 & 1.59556 \\
Eigenvalue 8 & 1.46039 & 1.53133 & 1.56317 \\
Eigenvalue 9 & 1.36856 & 1.49873 & 1.52986 \\
Eigenvalue 10 & 1.30482 & 1.46888 & 1.49218 \\
Eigenvalue 11 & 1.29328 & 1.43751 & 1.46663 \\
Eigenvalue 12 & 1.19744 & 1.40776 & 1.43309 \\
Eigenvalue 13 & 1.17152 & 1.38004 & 1.40644 \\
Eigenvalue 14 & 1.11022 & 1.35301 & 1.38136 \\
\hline
\end{tabular}

Figure 2. A numerical output generated by the software Vista-Visual Statistics that indicates the extraction of up to five factors 
description would require expansion and an increase in the number of items.

F2 consisted of four items related to the emotional expression of negative feelings. The skills of this group are important because negative emotions and the tension generated by them can lead to the consumption of alcohol or other substances as an escape valve for these maladaptive feelings (Monti et al., 2005). Expressing such feelings in an appropriate manner therefore increases the likelihood of social support and thus helps to maintain abstinence. Although the number of items was sufficient, the reliability was low in both the first extraction with five factors and the second extraction with four factors. One possibility for this scenario was that, in the extraction with four factors, new items could be grouped together, thus increasing the reliability of this factor. Another possibility was that in the three-factor extraction, a large dimension could be formed, including these items as, for example, "expressing feelings in general". However, none of these possibilities were confirmed.

Relative to the three factors that comprised the version of IDHEA-AD presented in this study, it should be emphasized that, in the process of maintaining abstinence, assertiveness appears to be the most important class of social skills in an environment that commonly stimulates substance consumption. This result was expected because assertiveness has typically been associated with good results regarding abstinence from substance use (Dolan et al., 2013; Duncan et al., 2000; Epstein et al., 2007; Ferrell \& Galassi, 1981; Freedberg \& Johnston, 1978 cited by Monti et al., 2005; Scheier et al., 1999; Zywiak et al., 2006; Witkiewitz et al., 2011). Carroll (1998), Monti et al. (2005) and Mares and Torres (2010) suggest a list of refusal skills necessary for the

Table 1

The Internal Structure of the Inventory of Anticipatory Coping Skills for Abstinence from Alcohol and Other Drugs with three factors

\begin{tabular}{|c|c|c|c|c|}
\hline \multirow{2}{*}{ Items } & \multicolumn{4}{|c|}{ Factors } \\
\hline & 1 & 2 & 3 & $h^{2}$ \\
\hline Refusing by stating they do not use the substance. & 0.75 & & & 0.53 \\
\hline Refusing by asking for no more offers. & 0.74 & & & 0.55 \\
\hline Refusing by stating that they stopped using the substance. & 0.73 & & & 0.51 \\
\hline Refusing by using appropriate tone of voice. & 0.72 & & & 0.57 \\
\hline Refusing offer and leaving the situation. & 0.70 & & & 0.43 \\
\hline Leaving the place of risk. & 0.67 & & & 0.39 \\
\hline Refusing by suggesting another activity. & 0.55 & & & 0.35 \\
\hline Refusing by changing the subject. & 0.54 & & & 0.38 \\
\hline Refusing by stating they are in treatment. & 0.53 & & & 0.30 \\
\hline Planning dates of risk. & 0.52 & & & 0.29 \\
\hline Evaluating engagement in risk situations in advance. & 0.49 & & & 0.35 \\
\hline Responding to the offer by indicating the downside of the substance. & 0.45 & & & 0.28 \\
\hline Using strategies to frequent places of risk. & 0.45 & & & 0.21 \\
\hline Requesting the inappropriate behavior to stop. & 0.42 & & & 0.26 \\
\hline Thanking for support received. & & 0.76 & & 0.57 \\
\hline Thanking for compliment about the changes made after sobriety. & & 0.69 & & 0.46 \\
\hline Dealing with mistakes by apologizing quickly. & & 0.67 & & 0.48 \\
\hline Expressing care and affection. & & 0.61 & & 0.39 \\
\hline Dealing with mistakes by apologizing without difficulty. & & 0.60 & & 0.38 \\
\hline Reciprocating care and affection. & & 0.59 & & 0.38 \\
\hline Listening attentively to advice. & & 0.58 & & 0.38 \\
\hline Admitting mistakes. & & 0.42 & & 0.22 \\
\hline Dealing with anger by thinking that it is a useless feeling. & & & 0.56 & 0.34 \\
\hline Dealing with anger using reassuring phrases. & & & 0.56 & 0.33 \\
\hline Dealing with anger by breathing deeply. & & & 0.56 & 0.32 \\
\hline Dealing with anger by analyzing the viewpoint of the other person. & & & 0.56 & 0.29 \\
\hline Dealing with disagreement by acting cautiously. & & & 0.53 & 0.29 \\
\hline Dealing with disagreement by performing a self-assessment. & & & 0.52 & 0.32 \\
\hline Dealing with anger by engaging in another activity. & & & 0.48 & 0.31 \\
\hline Dealing with disagreement by establishing agreements. & & & 0.42 & 0.23 \\
\hline \% Explained variance & 23.43 & 12.08 & 7.52 & \\
\hline Cronbach's alpha & 0.89 & 0.83 & 0.77 & \\
\hline
\end{tabular}


maintenance of abstinence in response to an offer of alcohol or other drugs: assertive refusal, suggesting alternatives, changing the conversation topic, offering a justification, requesting that the other person stop offering and ending the conversation. All these skills are present in the first IDHEA-AD factor, which explains the representativeness of the dimension and implies that the instrument evaluates this skill class well.

In addition to assertiveness for refusing substances, there are a number of different items that complement the first IDHEA-AD factor. These items evaluate planning to address risky places, and unlike refusal skills, which are obviously interpersonal, have an intrapersonal nature because they do not involve other people, but "mental resources" that the individual uses to address risk situations. Essentially, these items include skills to identify possible risk situations, to make decisions and plan appropriate activities to replace them when they occur, to cope with the situation safely or to scape the situation. Barkin et al. (2002) had previously pointed out the importance of decision making skills in this context. Such skills can be included in what Carroll (1998) calls "reducing the availability" of the substance. According to the author, for refusal skills to be more effective, it is also necessary to develop a repertoire of skills that lead to the reduced availability of the substance in the individual's daily environment. To remain abstinent while maintaining the identical activities that one participated in prior to abstinence is almost impossible. Hence, skills related to planning are relevant, which can decrease the frequency of risky locations and contact with individuals who can lead to risks. These skills are closely linked to refusal skills, which can be observed in F1 of the instrument, "assertiveness and planning for high-risk substance use situations".

The skills evaluated by F2 of the IDHEA-AD, "emotional expression of positive feelings for maintaining abstinence", are obvious regarding the anticipatory nature of the construct evaluated, once they involve behavior that aims to create a less stressful and more welcoming environment. This circumstance is evident by noting that the two major items of $\mathrm{F} 2$ evaluate the ability to take criticism appropriately and compliment support received in the behavior change process. The remaining items maintain this characteristic and involve the ability to receive compliments about the effort involved in maintaining abstinence, listening to advice, reciprocating positive affection from other people, apologizing in response to fair criticism and expressing affection to loved ones.

Because the addiction period for any substance is often marked by relationship problems, the ability to express positive emotion is important for maintaining abstinence, even in adverse situations. Complimenting, apologizing and expressing affection demonstrates that maladaptive behaviors, which are characteristic of addiction, are being replaced by other, adaptive behaviors that are connected to abstinence. These behaviors indicate to family and friends that there is behavioral change and, therefore, increase the likelihood of establishing a good relational environment and receiving social support, which may consequently decrease the chances of substance use occurrence or the severity of cravings and relapses. The skills in F2 are described in Monti et al. (2005). However, although these authors describe these skills separately, they were grouped together in the IDHEA-AD, thus suggesting that they are not completely independent, but rather subclasses of a larger class of coping skills. These skills all appear to have the direct function of generating a less confrontational atmosphere in common, thus favoring abstinence.

Unfortunately, studies about these skills are scarce. Monti et al. (1990) observed that, in the following months after a training course on communication skills in a program for alcohol addicted individuals, significant decrease on the level of use of the substance could be observed when compared to a program in which the training was not offered. Fathiandastgerdi et al. (2016) pointed out that a smaller repertoire of decision making, assertiveness, and communication, three components analysed by IDHEA-AD in F1 and F2, is a strong predictor of substances use amongst teenagers.

F3, "emotional self-control in adverse situations", consists mainly of anger management skills, although it also includes problem-solving skills related to interpersonal conflicts. Unlike the factors described above, which contained interpersonal skills, this factor is primarily represented by intrapersonal skills that are cognitive but also behavioral. The skills evaluated in this third dimension are required throughout the life of the individual to maintain abstinence, but appear to be even more necessary during the treatment period. In this phase, because of recent behavior problems related to alcohol or other drugs, individuals often become involved in interpersonal conflicts, often receive fair and unfair criticism, excessive demands, teasing or pressure to consume a substance. Emotional self-control is therefore necessary to act assertively, thus appropriately resolving the situation. The "feeling" of anger must be addressed properly so there are no "behavioral consequences of anger, such as aggression, impulsive actions, passivity and passive-aggressive behavior" (Monti et al., 2005, p. 114). According to these authors, it is not the feeling of anger itself, but the consequences of it that can increase the likelihood of consuming the substance, once they can create an environment of ineffective communication, emotional distance and hostility.

Monti et al. (1997) taught cocaine users skills to deal with situations in which they were frustrated and angry. The results showed that, in the three following months, those individuals decreased the use of cocaine and had shorter relapse periods when compared to the ones of the controlled group. Felicissimo et al. (2016) found out the alcohol addicts had a significant shorter repertoire 
of anger management skills than non-addict individuals. Wagner e Oliveira (2009) and Wagner et al. (2010) found the same results when studying marijuana users. Rahman et al. (2016) then stated that the lack of skills for dealing with negative emotions, such as anger or sadness, may contribute to the relapse of individual addicted in substances such as alcohol, marijuana and heroin.

A poorly developed repertoire of emotional self-control skills is therefore described as one of the factors that hinder the maintenance of abstinence, among other reasons, once it leads to passive or aggressive responses that facilitate the substance use. Assertive responses, which can contribute to abstinence, depend on emotional self-control. This link between assertiveness and emotional self-control is evident when one observes the higher correlation between the IDHEA-AD factors that evaluate these two repertoires (F1 and F3). A good repertoire of emotional self-control skills appears to assertively collaborate in establishing a healthier environment with good relationships and the ability to maintain abstinence.

The results presented in this study have some limitations that must be considered. First, there was no measure of the participant's level of involvement with the substance, and there was no strict control for the length of abstinence or possible comorbidities. In the first case, the information was based on the participant's own response, and in the second one, the information was received from the team working data collection.

The sample had a small number of women and many individuals with a low educational level. Furthermore, because all participants in treatment for illegal substance use stated crack cocaine was the most used drug, the study did not contemplate other types of illegal drugs. Although these are the present characteristics of public or charitable treatment services for substance addiction in Brazil, there is no guarantee that the results can necessarily be safely extrapolated.

Another limitation was the absence of control over the effect of interactions between the different types of drugs used by the participants in the sample. In substance addiction, it is uncommon to encounter individuals who only consume one drug type. In general, at least two drugs are used, such as the combination of crack cocaine with alcohol or marijuana. In this study, coping skills were only evaluated for the so-called "drug of choice", i.e., the drug that the participant deemed most difficult to abstain from. However, although there may be a preferred substance, many individuals use different substances in combination.

Although there were some limitations, the initial evidence based on the factor structure and internal consistency of the IDHEA-AD indicated that its validity and reliability were adequate. However, determining the quality of an instrument is a long and continuous process. Although this initial evidence will require frequent updates, other evidence based on external variables must also be developed. Future studies should involve, for example, collecting data on correlations of IDHEA-AD scores with other constructs and data on evidence of concurrent or predictive criterion validity. It would also be important to obtain more data on the internal structure of the instrument using Confirmatory Factor Analyses and investigations related to structural invariance. Once such evidence has been accumulated, the instrument can be considered for clinical or intervention efficacy evaluations. Currently, the use of this instrument is only recommended in research areas that expand and strengthen knowledge on the subject.

\section{Acknowledgement}

This research was partially suported by a grant from Fundação de Apoio à Pesquisa do Estado de São Paulo (FAPESP 2010/07890-3) and by Coordenação de Aperfeiçoamento de Pessoal de Nivel Superior (CAPES -12575-12-7). The authors would like to thank Luziane de Fátima Kirchner for her assistance with data collection and Fundação de Amparo à Pesquisa e ao Desenvolvimento Científico e Tecnológico do Maranhão ( FAPEMA) for the publishing support.

\section{References}

American Educational Research Association, American Psychological Association, National Council on Measurement in Education [AERA, APA, NCME] (1999). Standards for Educational and psychological testing. Washington, DC: Author.

Barkin, S. L., Smith, K. S., \& DuRant, R. (2002). Social skills and attitudes associated with substance use behaviors among young adolescents. Journal of Adolescent Health, 30(6), 448-454. doi: 10.1016/S1054-139X(01)00405-0

Blevins, C. E., Abrantes, A. M., \& Stephens, R. S. (2016). Motivational pathways from antecedents of alcohol use to consequences: A structural model of using alcohol to cope with negative affect. The American Journal of Drug and Alcohol Abuse, 42(4), 395-403. doi: 10.3109/00952990.2016.1141915

Caballo, V. E. (2003). Manual de avaliação e treinamento das habilidades sociais (Handbook of social skills evaluation and training). São Paulo: Santos. Carroll, K. M. (1998). A cognitive-behavioral approach: Treating cocaine addiction. Rockville: National Institute on Drug Abuse.

Conselho Federal de Psicologia (CFP) (2010). Avaliação psicológica: Diretrizes na regulamentação da profissão (Psychological evaluation: Guidelines on professional regulation). Brasília: CFP. 
Costello, A. B., \& Osborne, J. W. (2005). Best practices in exploratory factor analysis: Four recommendations for getting the most from your analysis. Practical Assessment Research \& Evaluation, 10(7), 1-9. Retrieved from http://pareonline.net/genpare.asp? wh=0\&abt=10

Del Prette, Z. A. P., \& Del Prette, A. (2002). Transtornos psicológicos e habilidades sociais (Psychological disorders and social skills). In H. J. Guilhardi, M. B. B. Madi, P. P. Queiroz, \& M. C. Scoz (Eds.), Sobre comportamento e cognição: Contribuições para a construção da teoria do comportamento (pp. 377-386). Santo André: ESETec.

Del Prette, Z. A. P., \& Del Prette, A. (2009). Avaliação de habilidades sociais: Bases conceituais, instrumentos e procedimentos (Social skills assessment: Conceptual bases, instruments and procedures). In Z. A. Del Prette, \& A. Del Prette (Eds.), Psicologia das habilidades sociais: Diversidade teórica e suas implicações (pp. 189-231). Petrópolis: Vozes.

Del Prette, Z. A. P., \& Del Prette, A. (2012). Social skills and behavior analysis: Historical proximity and new issues. Perspectivas em Análise do Comportamento, 1(2), 104-115. Retrieved from http://www.revistaperspectivas.org/v1n2

Dolan, S. L., Rohsenow, D. J., Martin, R. A., \& Monti, P. M. (2013). Urge-specific and lifestyle coping strategies of alcoholics: Relationships of specific strategies to treatment outcome. Drug and Alcohol Dependence, 128(1), 8-14. doi: 10.1016/j.drugalcdep.2012.07.010

Donovan, D. M. (2009). Avaliação dos comportamentos dependentes na prevenção da recaída (Assessment of addictive behaviors for relapse prevention). In D. M. Donovan \& G. A. Marlatt (Eds.), Avaliação dos comportamentos dependentes (pp. 1-50). São Paulo: Roca.

Duncan, T. E., Duncan, S. C., Beauchamp, N., Wells, J., \& Ary, D. V. (2000). Development and evaluation of an interactive CD-ROM refusal skills program to prevent youth substance use: "Refuse to use". Journal of Behavioral Medicine, 23(1), 59-72. doi: 10.1023/A:1005420304147

Epstein, J. A., Zhou, X. K., Bang, H., \& Botvin, G. J. (2007). Do competence skills moderate the impact of social influences to drink and perceived social benefits of drinking on alcohol use among inner-city adolescents? Prevention Science, 8(1), 65-73. doi: 10.1007/ s11121-006-0054-1

Fathiandastgerdi, Z., Eslami, A. A., Ghofranipour, F., Mostafavi, F., \& Ebrahimi, A. A. (2016). The relationship between self-efficacy, coping skill and substance use in adolescent: Based on structural equation modeling. Journal of Substance Use, 21(3), 287-293. doi: $10.3109 / 14659891.2015 .1018973$

Felicissimo, F. B., Casela, A. L. M., \& Ronzani, T. M. (2013). Habilidades sociais e alcoolismo: Uma revisão da literatura. Psicologia em Estudo, 18(1), 137-145. doi: 10.1590/S1413-73722013000100014

Felicissimo, F. B., Santos, J. A., Fontoura, L. O., \& Ronzani, T. M. (2016). Habilidades sociais em alcoolistas: Um estudo comparativo. Psicologia: Teoria e Pesquisa, 32(2), 1-6. doi: 10.1590/0102-3772e322212

Ferrel, W. L., \& Galassi, J. P. (1981). Assertion training and human relations training in the treatment of chronic alcoholics. International Journal of the Addictions, 16(5), 959-968. doi: 10.3109/10826088109038905

Field, A. (2005). Discovering statistics using SPSS (2 $2^{\text {nd }}$ ed.). London: Sage.

Hair, J. F., Black, W. C., Babin, B. J., Anderson, R. E., \& Tatham, R. L. (2009). Análise multivariada dos dados (6th ed.) (Multivariate data analysis). Porto Alegre: Bookman.

Hair, J. F., Babin, B., Money, A. H., \& Samouel, P. (2005). Fundamentos de métodos de pesquisa em administração (Essentials of business research methods). Porto Alegre: Bookman.

Horta, R. L., Schäfer, J. L., Coelho, L. R. M., Rodrigues, V. S., Oliveira, M. S, \& Teixeira, V. A. (2016). Condições associadas a prejuízo de desempenho em habilidades sociais em uma amostra de conveniência de usuários de crack. Cadernos de Saúde Pública, 32 (4), e00010715. doi: 10.1590/0102-311X00010715

Humke, C., \& Radnitz, C. L. (2005). An instrument for assessing coping with temptation: Psychometric properties of the Alcohol Abuse Coping Response Inventory. Substance Use and Misuse, 40(1), 37-62. doi: 10.1081/JA-200030493

Litt, M. D., Kadden, R. M., \& Tennen, H. (2012). The nature of coping in treatment for marijuana dependende: Latent structure and validation of the coping strategies scale. Psychology of Addictive Behaviors, 26(4), 791-800. doi: 10.1037/a0026207

Mares, M. F., \& Torres, L. B. (2010). Mantenimiento de las habilidades de rehusarse al consumo en usuarios crónicos de alcohol y drogas: Un estudio de casos. Salud Mental, 33(1), 47-55.

Marlatt, G. A., \& Witkiewitz, K. (2009). Problemas com álcool e drogas (Relapse prevention for alcohol and drugs problems). In: G. A. Marlatt \& D. M. Donovan (Eds.), Prevenção da recaída: Estratégias de manutenção no tratamento de comportamentos adictivos 2 nd ed. (pp. 15-50). Porto Alegre: Artmed.

Monti, P. M., Abrams, D. B., Binkoff, J. A., Zwick, W. R., Liepman, M. R., Nirenberg, T. D., \& Rohsenow, D. J. (1990). Communication skills training, communication skills training with family and cognitive behavioral mood management training for alcoholics. Journal of studies on alcohol, 51(3), 263-270. doi: 10.15288/jsa.1990.51.263

Monti, P. M., Kadden, R. M., Rohsenow, D. J., Cooney, N. L., \& Abrams, D. B. (2005). Tratando a dependência de álcool: Um guia de treinamento das habilidades de enfrentamento (Treating alcohol dependence: A coping skills training guide). São Paulo: Roca.

Monti, P. M., Kadden, R. M., Rohsenow, D. J., Michalec, E., Martin, R. A., \& Abrams, D. B. (1997). Brief coping skills treatment for cocaine abuse: Substance use outcomes at three months. Addiction, 92 (12), 1717-1728. doi: 10.1111/j.1360-0443.1997.tb02892.x

Rahman, M. M., Rahaman, M. M., Hamadani, J. D., Mustafa, K., \& Islam, S. M. S. (2016). Psycho-social factors associated with relapse to drug addiction in Bangladesh. Journal of Substance Use, 21(6), 627-630. doi: 10.3109/14659891.2015.1122099

Rangé, B., \& Marlatt, G. A. (2008). Cognitive-behavioral therapy for alcohol and drug use disorders. Revista Brasileira de Psiquiatria, 30 (2), 88-95.

Ritchie, G., Weldon, S., Freeman, L., MacPherson, G., \& Davies, K. (2011). Outcomes of a drug and alcohol relapse prevention programme in a population of mentally disordered offenders. British Journal of Forensic Practice, 13(1), 32-43. doi: 10.5042/bjfp.2011.0048

Rohsenow, D. J., Martin, R. A., \& Monti, P. M. (2005). Urge-specific and lifestyle coping strategies of cocaine abusers: Relationships to treatment outcomes. Drug and alcohol dependence, 78(2), 211-219. doi: 10.1016/j.drugalcdep.2005.03.001

Sá, L. G. C., \& Del Prette, Z. A. P. (2014). Habilidades Sociais como preditoras do envolvimento com álcool e outras drogas: Um estudo exploratório (Social Skills as Predictors of Alcohol and Other Drugs Involvement: An Exploratory Study). Interação em Psicologia, 18(2), 167-178. doi: 10.5380/psi.v18i2.30660

Sá, L. G. C., \& Del Prette, Z. A. P. (2016). Habilidades de enfrentamento antecipatório para abstinência de substâncias: Construção de um novo instrumento de medida (Anticipatory coping skills for substance abstinence: Construction of a new measuring scale). Avances en Psicología Latinoamericana, 34(2), 351-363. doi: 10.12804/apl34.2.2016.09

Sakiyama, H.M.T., Ribeiro, M. \& Padin, M.F.R. (2012). Prevenção de recaída e habilidades sociais (Relapse prevention and social skills). In M. Ribeiro \& R. Laranjeira (Eds.), O tratamento do usuário de crack (pp. 337-350). Porto Alegre: Artmed. 
Scheier, L. M., Botvin, G. J., Diaz, T., \& Griffin, K. W. (1999). Social skills, competence and drug refusal efficacy as predictors of adolescent alcohol use. Journal of Drug Education, 29(3), 251-278. doi: 10.2190/M3CT-WWJM-5JAQ-WP15

Schneider, J. A., Limberger, J., \& Andretta, I. (2016). Habilidades sociais e drogas: Revisão sistemática de produção científica nacional e internacional (Social skills and drugs: Systematic review of national and international scientific production). Avances en Psicología Latinoamericana, 34(2), 339-350. doi: 10.12804/apl34.2.2016.08

Tabachnik, B. G., \& Fidell, L. S. (2007). Using Multivariate Statistics (5th ed.). Boston: Pearson.

Trower, P. (1995). Adult social skills: State of the art and future directions. In W. O’Donohue \& L. Krasner (Eds.), Handbook of psychological skills training: Clinical techniques and applications (pp. 54-80). New York: Allyn and Bacon.

Van Gundy, K. T., Howerton-Orcutt, A., \& Mills, M. L. (2015). Race, coping style, and substance use disorder among non-hispanic african american and white young adults in South Florida. Substance Use \& Misuse, 50(11), 1459-1469. doi: 10.3109/10826084.2015.1018544

Van Hasselt, V. B., Hersen, M., \& Milliones, J. (1978). Social skills training in alcoholics and drug addicts: A review. Addictive Behaviors, 3(3-4), 221-233. doi: 10.1016/0306-4603(78)90023-0

Wagner, M. F., \& Oliveira, M. S. (2009). Estudo das habilidades sociais em adolescentes usuários de maconha (The social skills study in adolescents marijuana users). Psicologia em Estudo, 14(1), 101-110. doi: 10.1590/S1413-73722009000100013

Wagner, M. F., Silva, J. G., Zanettelo, L. B., \& Oliveira, M. S. (2010). O uso da maconha associado ao déficit de habilidades sociais em adolescentes (The association between marijuana use and social skill deficit in adolescents). Revista Eletrônica Saúde Mental, Álcool e Drogas, 6(2), 255273. doi: 10.11606/issn.1806-6976.v6i2p255-273

Witkiewitz, K. Aracelliz, N., Hartzler, B., \& Donovan, D. M. (2011). Drinking outcomes following drink refusal skills training: Differential effects for a african American and non-hispanic white clients. Psychology of Addictive Behaviors, 25(1), 162-167. doi: 10.1037/a0022254

Zywiak, W. H., Stout, R. L., Longabaugh, R., Dyck, I., Connors, G. J., \& Maisto, S. A. (2006). Relapse-onset factors in Project MATCH: The Relapse Questionnaire, Journal of Substance Abuse Treatment, 31(4), 341-345. doi:10.1016/j.jsat.2006.05.007

\section{About the authors}

Lucas Guimarães Cardoso de Sá is a professor at the Psychology Department of the Federal University of Maranhão (Universidade Federal do Maranhão - UFMA). He has an undergraduate and a Masters degree in Psychology by the Federal University of Uberlândia (Universidade Federal de Uberlândia - UFU) and a PhD in Psychology by the Federal University of São Carlos (Universidade Federal de São Carlos - UFSCar). Psychologist in the Department of Attention to Chemical Dependencies in UFU between 2006 and 2010 . Coordinates the Group of Studies and Research in Psychometrics and Psychological Evaluation (Grupo de Estudos e Pesquisas em Psicometria e Avaliação Psicológica-GEPPAP/UFMA).

Fabián Orlando Olaz has a PhD in Psychology. Director of the Laboratory of Interpersonal Behavior (Laboratorio de Comportamiento Interpersonal - LACI). Professor of Psychology at the National University of Cordoba (Universidad Nacional de Córdoba - UNC), Argentina. Psychotherapist, specialist in Contextual Behavioral Psychotherapy and Mindfulness. Specialist in Acceptance Therapy and Commitment and Functional Analytical Psychotherapy.

Zilda Aparecida Pereira Del Prette holds an undergraduate degree in Psychology by the State University of Londrina (Universidade Estadual de Londrina), a Masters degree in Psychology by the Federal University of Paraíba (Universidade Federal da Paraíba), PhD in Psychology by the University of São Paulo (Universidade de São Paulo) and postdoctorate in Psychology of Social Skills by the University of California. Currently, she is a level 1A researcher in CNPq and Professor at the Federal University of São Carlos (Universidade Federal de São Carlos), linked to the Graduate Programs in Psychology of the Federal University of São Carlos. 